\title{
Using Arbitration for Resolving Foreign Investment Disputes: A Comparative Study of Laws on Arbitration in Ghana and China
}

\author{
Shirley Ayangbah ${ }^{1} \&$ Liu Sun ${ }^{1}$ \\ ${ }^{1}$ Law School, Zhongnan University of Economics and Law, Wuhan, China \\ Correspondence: Shirley Ayangbah, Law School, Zhongnan University of Economics and Law, Wuhan, China. \\ Tel: 86-188-0272-6185. E-mail: shirlessa@yahooo.com
}

\author{
Received: March 22, 2016 Accepted: May 14, 2016 Online Published: June 23, 2016 \\ doi:10.5539/jpl.v9n7p1 URL: http://dx.doi.org/10.5539/jpl.v9n7p1
}

\begin{abstract}
International Investment in recent times is seen as one of the fastest-developing areas of international law. In the past decades, there has been a dramatic increase in the number of bilateral investment treaties and other agreements with investment related provisions that grant foreign investors important substantive and procedural rights, including, most importantly, the right to sue individuals, organizations and even the state hosting their investment for violations of customary international law and treaty obligations. Dispute becomes an inevitable phenomenon as individuals, organizations and countries continue to engage in foreign investment and as such there is the need for dispute solving mechanism to resolve such disputes as and when they arises. Even though there are several dispute solving mechanisms, arbitration seems to be a well-established and widely used mechanism to end dispute probably due to the efficiency and flexibility nature of it. The laws governing arbitration differ from one country to the other and it is for this reason that investors need to be abreast with the different arbitration laws so as to enable them make inform decisions as to whether to resort to arbitration or not. This paper analyses the arbitration laws of The Republic of Ghana and Peoples Republic of China in a comparative manner by drawing on the similarities and difference with respect to arbitration laws and procedure in these two countries. The paper is divided into three parts. The first part of this paper gives a brief background as well as the characteristics of the concept of arbitration. The second part looks as the similarities and difference of arbitration between the selected countries, and the final part looks at the arbitration phase and post arbitration phase of the two countries.
\end{abstract}

Keywords: arbitration, foreign investment, China, Ghana, dispute resolution

\section{Introduction}

Arbitration in its simplest form could be defined as the submission of a dispute by agreement of both parties to a fair and impartial third person or persons chosen by the parties in the dispute about a contentious issue, and agree among each other in advance to obey and abide with the final award issued by the arbitrator - a decision made after hearing of the case of which both parties who are in disagreement are granted opportunity to argue their case out, (Arbitration, West's Encyclopedia of American Law, 2008). In a broader sense, five most important characteristics of arbitration can be identified. These are arbitration is by mutual agreement, the parties in disagreement designate the arbitrator(s), arbitration is not biased to one particular side, arbitration is a private and secret procedure, and the decision made by the arbitral tribunal after hearing the case is final (Bennett, 2010).

Arbitration is increasingly becoming a well-established and widely used means of settling disputes and this could probably be due to the numerous theoretical advantages that arbitration has over litigation. The greatest advantage of arbitration is efficiency. Advocates say arbitration is easier, cheaper, and faster (Arbitration, West's Encyclopedia of American Law, 2008). Another important advantage is the greater flexibility with which parties in arbitration can shape the terms and rules of the process (Arbitration, West's Encyclopedia of American Law, 2008).

The laws governing arbitration as a mechanism for settling foreign investment disputes are subjective as countries adopted different arbitration procedure and laws in seeking redress. In this regard, a comprehensive knowledge and understanding of a country's arbitration procedure as prescribed by the countries legal system is of great importance to investors as it will help them to make informed decisions as to whether to resort to 
arbitration to settle foreign investment dispute or not. It is in the light of this that this paper seeks to comparatively analyze the arbitration laws of The Republic of Ghana and that of the People's Republic of China (PRC).

\subsection{Methodology of the Study}

In order to comprehensively analyze the similarities and difference between the Republic of Ghana and that of the People's Republic of China as far as the use of arbitration as means of settling foreign dispute is concerned, this study adopts a comparative analysis as a research methodology with the aim of identifying the unique and distinctive features peculiar to the two countries regarding the use of arbitration to settle foreign disputes as and when such disputes arises.

The data obtained from the two countries were qualitatively analyzed in an objective manner so as to outline the difference and similarities between the two countries in the process of using arbitration to resolve foreign disputes. As noted by (Burnham et al., 2004, cited in Morris, 2009), qualitative analysis generates a wide range of data from different sources and enables a comprehensive a detailed analyses of a phenomenon. It offers a detailed and in-depth explanation to the subject under investigation in a more comprehensive manner.

The study did not make use of any primary source of data but however, it thoroughly reviewed literature and secondary data on the laws and processes of using arbitration to resolve foreign disputes in the two countries. A thorough review and analyses of secondary data on the laws, procedure and processes of using arbitration to resolve foreign disputes in the two countries went a long way in helping to comparatively and objectively outline and analyzed the difference and similarities in the two countries as far as the use of arbitration to resolve foreign disputes is concerned.

\section{Similarity between Ghana and China's Arbitration System}

\subsection{Written Form}

The greatest and perhaps the most significant similarity that can be drawn from the two legal system could be seen in the recognition of a valid arbitration agreement in a "written form". According to the Convention on the Recognition and Enforcement of Foreign Arbitral Awards, 1958 which was held in New York, Arbitration laws, procedures and agreements are to be in written form, and it must include an arbitral clause which should be stated in the contract or in the arbitration agreement, to which both parties are expected to sign. (Arbitration Convention at 49; Van Den Berg, 1996). Such definition is stressed on in Article 16 of the Chinese Arbitration Law in 1995. The PRC 1995 arbitration law stipulates that "an agreement for arbitration shall comprise of an arbitration clauses which is specifically stated in the contracts or other written contract for arbitration reached earlier or after a disagreement occurs"(Jingzhou, 2011). Article 11 of the PRC contract law provides that written agreements shall take the form of digital telecoms for example fax, online messages or Electronic mails (Contract Law of PRC, 1999).

In a similar situation as in the case of Ghana, section 2(1) of Alternative Dispute Resolution Act, 2010 stipulates for an arbitration agreement in a written form (Ghana's Alternative Dispute Resolution Act, 2010; Nene Amegatcher, 2011). The Act continuous to describes written forms to include letters, Electronic-mail, fax or any other medium of communication which has the capacity or capability of providing records for the agreement. Thus both the Chinese and the Ghanaian laws on arbitration are in line with The New York Convention on the Recognition and Enforcement of Foreign Arbitral Awards. The main aim of this provision is to look at the intention and purposes of exchange of communication between the two parties so as to be certain that parties have agreed to resort to arbitration in solving their dispute.

\subsection{Language of Arbitration}

Another similarity that could be identified in the foreign investment laws of the two countries is the choice that parties have to make a choice with regards to the language to be used for the arbitration procedure. In this era and age where there a lot of spoken language in different parts of the world, it becomes important to pay attention to the language provision and it is for this reason that Ghana's Alternative Dispute Act, section 32 allows parties to choose the language for proceedings (Ghana's Alternative Dispute Resolution Act, 2010 ; Nene Amegatcher, 2011). China on the other hand states that as a matter of ethical standards, the arbitral proceedings to a large extent should be conducted in Chinese language. However, the parties are also granted the opportunity to agree among themselves to carry out the arbitral proceedings in a foreign language of their choice. (CIETAC Arbitration Rules 2015, art 81(1), Ulrike Glück and Falk Lichtenstein, 2014). 


\section{Differences between Ghana and China's Arbitration Systems}

The difference between the two countries arbitration system could be seen in the areas of arbitration validity, ad-hoc arbitration, doctrine of 'kompetenz-kompetenz', list of jury of arbitrators, the country of origin of arbitrators, exemption from prosecution (immunity) of arbitrators, counsel of the party and party autonomy. A detail discussion of these concepts could be seen below:

\subsection{Arbitration Validity}

To begin with, the Chinese legal system requires that an arbitration agreement must formally choose an arbitration institution before the Arbitration could be seen as a valid one. (Article 16 of China's Arbitration Act; Cleary Gottlieb, 2014). This requirement has been criticized by the international arbitration community; such a requirement not only over burdens the parties but also refuse to notice the parties' intention to arbitrate as well as the recent prevailing style of international arbitration as recognized by the international community as far as the usage of arbitration is concerned (Chi, 2008). Infact, refusing to give recognition to an arbitration agreement that does not choose an arbitration institution intentionally do away with the parties' independence and ability to have a free choice in the arbitration procedure. This is not the case in Ghana. The Ghanaian law on arbitration does much to recognize and uphold the general principle of party autonomy, respecting and securing the ability of parties to choose that disputes between them be finally dealt with by arbitration and to determine how such arbitration will be conducted (Sarkodie, 2011). Section 5(1) of the Ghanaian Alternative Dispute Resolution, Act, provides that, "a party to a disagreement to which there is an arbitration agreement reached between the parties in contention could, submit to the terms of that agreement, refer the dispute to arbitration". In this way the Act gives recognition and upholds the right of contracting parties to agree to arbitrate and by such making the agreement to arbitrate valid.

Another important issue that attention needs to be paid to is the definition of "arbitration commission" as provided for under Article 16 of China's Arbitration Law (CAL) (China Arbitration Law, art. 16(4)). This provision states that parties cannot chose any random arbitration commission, but it should rather be an arbitration commissions which is registered in China under the CAL (Article 10 of China Arbitration Law). A direct implication of this is that, foreign or international arbitration institutions are eliminated from the available list of arbitration institutions from which parties seeking arbitration in China can chose from (Jingzhou \& Wunschheim, 2007). However in the Ghanaian context, Parties are allowed to select any arbitration Commission of their choice whether or not they are registered in Ghana and this is in direct compliance with International Chamber of Commerce (ICC). As it is widely the believed that open competition could flourish the growth of Chinese arbitration system, some Chinese scholars have a different view as some Chinese scholars argue that international commercial arbitration to a large extent is a legal service and China is not obliged to open up its market to foreign competitors due to the fact that China did not make any commitment to the World Trade Organisation (WTO) and its member states. Also, the legal service sector with regards to arbitration for example involves judicial sovereignty (Gao, 2008).

\subsection{Ad Hoc Arbitration}

Ad hoc arbitration is a well- set up form of arbitration (Chu, 2011) that came into existence before expected time than institutional arbitration in the world. This is however, not given recognition in China in the arbitration procedure (Zhao, 2007: Xia, 2011). It is only institutional arbitration that has a formal recognition in Mainland China. In a situation where an agreement makes provision for arbitration in Mainland China but does not state explicitly an arbitral institution, such an agreement or contract is therefore not valid arbitration agreement. This provision could be found in articles 16 and 18 of CAL(Articles 16 and 18 of China Arbitration Law),which demands that an arbitration agreement must include the name of an arbitration institution and therefore implies that ad hoc arbitration is not given any formal recognition . For instance, in 2004 the Supreme Court of China instructed its lower court not to give recognition of an arbitration clause that states, "Arbitration: ICC Rules, Shanghai shall apply,". The reason been given by the Supreme Court for such decision was that, the arbitration clause did not bear an arbitration commission (Supreme People's Court Min Si Ta Zi (2003)). Such a requirement is rare and uncommon in international practice. In most cases as far as international practice is concerned, parties frequently consent to arbitration rules without necessarily designating an arbitration institution in their arbitration contract. Ad hoc arbitration is thus not an alternative in Mainland China. Prior to the Arbitration Law of 1995, Chinese law was mute about this phenomenon as well as the validity of its arbitration contract and as a result, an ad hoc arbitration agreement is not valid (Samassekou \& Lianbin, 2011). Regardless of these provisions, it is important to however note that foreign ad hoc arbitration awards have been implemented in China, for example, the case of Guangzhou Ocean Shipping Company v Marships of 
Connecticut (1990) (Arbitration Convention, arts. 1, 10) gave recognition to and enforced three arbitral awards given by an ad hoc tribunal in London. Ad hoc arbitration award given in Hong Kong are also recognized and enforced in the Peoples Republic of China (PRC) (Articles 16 and 18 of PRC Arbitration Law, p. 4.).

The case of Ghana is different but in line with International practices. Under the Ghana legal system, the Government of Ghana (GOG) has shown a symbolic interest in handling disputes under the ad hoc arbitration rules as determined by the U N Commission on International Trade Law (UNCITRAL Model Law). This means that ad hoc arbitration is recognized and allowed in Ghana. Therefore, when the parties engaging in a contract write out an arbitration clause, they are at liberty to decide whether they wish to have their arbitration in the context of an institution or by ad hoc arbitration (U.S. Department of State-Ghana, 2015).

\subsection{Doctrine of Kompetenz-Kompetenz}

The doctrine of kompetenz-kompetenz in simple terms provide provides that the arbitral tribunal has the authority to reconsider and make a decision on the effectiveness of an arbitration contract and logically determine the range of legal authority of the arbitral tribunal (Jingzhou, 2012). This concept is rooted in the theory of autonomy and stresses on the independence and ability of the arbitral tribunal.

This doctrine is widely acknowledged in many circles both in theory as well as in practice. China however, has not yet adopted this concept. According to Article 20 of the CAL, in case the parties challenge the validity of an arbitration contract, a request shall be sent to the arbitration institution to take a decision or to the People's Court for a decision to be taken (Article 20 of PRC Arbitration Law, p. 4). If one party decides to refer to the arbitration institution for a decision to be taken and the other party on the other hand refers to the People's Court for a decision to be taken, the arbitration institution shall halt its proceeding and grant jurisdiction to the People's Court to make a decision on the validity of the arbitration contract. This therefore implies that, in China, even though both the People's Courts as well as arbitration institutions have the authority to review the effectiveness of arbitration contract; the power to rule on the validity of an arbitration contract is solely invested in the Peoples court and not in the arbitral tribunal (Jingzhou, 2011).

The case is different from that of Ghana. The fundamental issue of the tribunal's power to give a ruling on its own substantive jurisdiction is addressed in the Act at section 24, which expressly states that (unless the parties otherwise consent) the tribunal shall rule on its own jurisdiction. This section confirms that the tribunal may do so "particularly in respect of": the existence, scope and validity of the arbitration agreement (Alternative Dispute Resolution Act, 2010, the existence or validity of the principal agreement; and whether the matters presented to arbitration are in conformity with the arbitration contract. It should be noted that, following the tribunal's ruling with regard to its jurisdiction, a dissatisfied party may submit an application to the legally empowered authority or the High Court (Alternative Dispute Resolution Act, 2010) to determine the tribunal's range of legal authority. Section 26(4) confirms that (unless the parties agree to the contrary) such an application shall not operate in arbitral proceedings. This therefore allows a tribunal which has ruled positively regarding its jurisdiction to proceed to hear the dispute, notwithstanding continuing jurisdictional disputes. Where, therefore, the parties fail to reach a consensus as to the conduct of the arbitration and/or any procedural or evidential questions which arise in the course of the arbitration, the tribunal is explicitly empowered to determine how matters shall proceed.

\section{Arbitrators}

\subsection{Panel or Juries of Arbitrators}

The panel or juries of arbitrators could be defined as a group of arbitrators of which parties' in contention can select from. In theoretical sense, parties shall be entitled to freely choose any person or group of persons they trust and feel comfortable with to represent them as their arbitrators, provided these selected people remain independent and not bias - this in actual fact is essence of arbitration, however, the case is a little different in China. Although in principle, parties are allowed to select arbitrators outside of the panel, such sections must receive the approval of the China International Economic and Trade Arbitration Commission (CIETAC's) which often turn out not be accepted (Jingzhou, 2011). This phenomenon to a large extent excludes the parties' freedom of choice outside the arbitration panel. In the case of Ghana, if the parties names an Arbitrator or state explicitly a method of selecting an Arbitrator, that method must be abided by (Section14 (I) of Alternative Dispute Resolution Act, 2010).

It must also be noted that if a party submit a request with regards to the appointing party, the center shall made available a list of members of the panel to that party from which the party has the liberty, if it so wishes, make the appointment from the provided list. The center makes the appointment of the arbitrators only when the parties have failed to make such appointment (Section 14(II) of Alternative Dispute Resolution Act, 2010). 


\subsection{The Country of Origin of Arbitrators}

By international standards and practice it is an important prerequisite that the sole or chief arbitrator of a three-member tribunal panel must have a distinct nationality from those of the parties in contention. This provision could also be found in lots of arbitration rules of international arbitration institutions, such as Hong Kong International Arbitration Centre (HKIAC) (Wang, 2013) and the International Chamber of Commerce (ICC) (International Chamber of Commerce, Rules of Arbitration, 2010). This practice is not different from that of Ghana. The sole arbitrator or the neutral arbitrator shall upon the request of either party be appointed from among the nationality of a country other than that of any of the parties (Section 16 of Alternative Dispute Resolution Act, 2010). However in the case of China, the situation is not the same as there is no similar clause available in the arbitration rules of Chinese arbitration institutions which conforms or support this assertion, and, unless the parties have consented in their arbitration contract that the chief or sole arbitrator shall be a third country citizen, the chief or sole arbitrator in most of the foreign-related cases arbitrated in Chinese arbitration institutions in most cases happens to be a Chinese national (Jingzhou, 2011).

\subsection{Exemption from Prosecution (Immunity) of Arbitrators}

In most countries, it is enshrined in their law that the arbitrators are exempted from responsibility or prosecution. In other words, the immunity of arbitrators from civil liabilities arising from arbitration are protected by the law of most countries so as to enable arbitrators carry out their duties without fear or favour, but there is no explicitly stated provision in PRC law guaranteeing the immunity of arbitrators. Article 38 of CAL states that: "An arbitrator who violates one of the circumstances or issues as described in Item 4 of Article 34 (Jingzhou, 2011), or an arbitrator who engage in those circumstances stated in Item 6, Article 58 (Article 34(4) of China Arbitration Law, 4), shall be subjected to legal liabilities as stated in the law and the arbitration commission shall take away his or her name from the list of arbitrators." The law in Ghana is silent on the immunity of arbitrators but arbitrators must be impartial so as to effectively deliver in a professional way what was expected from them as against the UNCITRAL Model Law, which requires "independence" as well as impartiality (Sarkodie, 2011).

\section{Counsel of the Parties}

Another important issue regarding arbitration has to do with the counsel of the parties. Even though China has officially permitted the operation of foreign law firms in China, especially, since China became a member of WTO, foreign law firms are not allowed to issue opinions in the legal competence of an attorney on the application of Chinese laws as far as arbitration activities are concerned. Thus it is almost impossible for foreign law firm to represent clients in arbitration proceedings in China. However, this restriction has witnessed some modification since 1956. Even during the darkest period in China where the principle of free representation for arbitration by foreign nationals was permitted, (St. Council of the People's Republic of China, art. 15, 2011) in situations where Chinese law is the applicable law to the agreement in contention, foreign law firms did not have the option of free representation but rather were compelled to hire the services of a local law firm. (Article 22 of CIETAC Rules, 2000). This practice is different from that of Ghana, any party is entitled to be represented by counsel. However, the Party that has the intention of being represented by counsel needs to inform the other party and the centre with some details of the counsel like the name and address of counsel at least three days before the date set for hearing of which the counsel is to make his first appearance (Section 22 of Alternative Dispute Resolution Act, 2010).

\section{Party Autonomy}

According to Tao, "an important criterion for assessing whether a country is a friendly venue for international arbitration is to make a critical assessment of how the judges with the legal authority to enforce laws are in support of arbitration" (Jingzhou, 2008). The habitual use of judicial review in the processes of arbitration can not necessarily make arbitration more "legal," but rather it contrary has an effect on the development of arbitration as a mechanism for resolving disputes between parties' with free choice. This practice looks similar to that of Ghana but the courts interfere in a different situation. The Act confers extensive powers on the courts to assist and support the arbitral process in relation to the constitution, fee entitlement and liability of the tribunal (Sarkodie, 2011). In this case party autonomy is not jeopardized. It is important to mention that the courts of Ghana have been advised to be mindful of the overriding aims and spirit of the Act that is to say the promotion of arbitration as an efficient, effective and final means of dispute resolution, which works in harmony, rather than in competition, with the courts. 


\section{Arbitration Phase}

The Arbitration phase in this context has to do with granting relief (interim) upon parties pending final determination of the dispute before them. In general terms, interim measures are instituted with the primary aim of maintaining that the parties held respectively in their initial agreement (the 'status quo'), or prevent the demolishing of proof of evidence and to avoid the loss or disappearance of valuable items that are the subject of the contention, (Willems, 2014).

\subsection{Interim Measures}

In international commercial arbitration practice both the judicial courts, as well as the arbitral tribunals are granted the authority to give interim measures upon receiving an application from a party (Jingzhou, 2011). In China, it is only the People's Courts that has the power to grant interim measures upon receiving an application from a party. According to laws of China, when a party makes an application for preservation of property or evidence, the arbitral tribunal upon receiving such application, shall submit the application through the arbitration commission to be determine by a relevant competent court; both the arbitral tribunal and arbitration commission do not possess the legal authority to issue an order for the preservation of evidence or property (Article 17 of UNCITRAL Model Law on International Commercial Arbitration, 1985)). However, in the Ghanaian context, the arbitrator may, at the request of a party, grant any interim relief if the arbitrator deem it important for the purpose of safeguarding or preservation of property (Kuenyehia, 2011; Section38, Alternative Dispute Resolution Act, 2010). This implies, the court does not reserve the sole right to grant an interim relief measures as in the case of China but any party has the right to apply for interim relief measures if the party deems fit that such interim relief measures are very crucial for the protection and preservation of the party's property and bear the cost for the request as prescribed by the Ghanaian laws.

\section{Post-Arbitration Phase}

The post arbitration phase is characterized by the enforcement of arbitral awards. The significance of deciding to arbitrate is to settle disputes and most essentially render awards void of either party resorting to the domestic court of its foreign partner (Farina, 2011).

\subsection{Enforcement of Arbitral Awards}

A key feature of arbitration is the finality of the award. These awards can be classified as both domestic and foreign. In a broader sense, two main ways are available to stop the execution of an arbitral award. These are either to initiate a set-aside procedure or place an objection on the enforcement of the arbitral award. The specific legal way of addressing this issue, the procedure to follow as well as the relevant grounds differ depending on the nationality of the arbitral award, and also on whether there is any foreign element involve (Jingzhou, 2008). In the case of pure domestic arbitral awards, thus an award granted by an arbitral tribunal sitting in China which does not involve any foreign elements, the People's Court have the power to revise the procedures and merits of the case before allowing enforcement of the award. Cancellation or non-enforcement of the award is possible in the process of review by the People's Court. In cases where there is a foreign-related arbitral awards the People's Court have the power to only review the procedural matters of the case and may allow enforcement, cancellation or prevent the enforcement of the award (Article 58 of China Arbitration Law).

In the case of Ghana, the recently enacted Ghanaian Alternative Dispute Resolution Act, 2010 (Act 798) controls both foreign as well as domestic arbitral awards. The Act governs the enforcement of foreign arbitral awards in Ghana, providing for enforcement pursuant similar to the provisions of the New York Convention. Section 59 of the Act provides that the High Court of Ghana will enforce a foreign arbitral award made under the New York Convention and not subject to a pending appeal. The party wishing to enforce the award must produce the award in question and the agreement following which the award was made (New York Convention Section 59(3), 1958).

\section{Conclusion}

One can infer from the above that the arbitration laws and procedure of the two countries differ completely from one another. The arbitration laws of Peoples Republic of China is quite rigid leaving a little room for flexibility and it is for such reasons and others that Distribution Contract stated that China International Economic and Trade Arbitration Commission (CIETAC) arbitration is mostly not liked by foreign investors for resolving non-trade disagreements, but on the other hand it is usually proposed by Chinese parties as their preferred choice for resolving disputes by the use of arbitration. It is perhaps for this reason that CIETAC arbitration provisions was suggested to set out a template with the aim to improve and address most of the significant concerns foreign parties have in relation to CIETAC arbitration in this context.. The arbitration laws of Ghana on the other 
hand are a little flexible probably to encourage investors to use arbitration to amicable resole their disputes so as to save time and money and also reduce the burden on the court systems. Regardless of the content of a country's arbitration laws, the fact still remains that foreign investors need to get themselves abreast with the arbitration laws and procedure of the country of their investment so as to be able to decide whether to resort to arbitration to resolve foreign investment dispute or not.

\section{Acknowledgement}

My heartfelt appreciation goes to my supervisor, Professor Liu Sun, Director of the department of International Economic Law, Zhongnan University of Economics and Law for exerting the necessary intellectual influence to ensure this work meets scholarly standard. Not forgetting Dr. Alfred Sarbah of the Institute of Distance Learning \& Continuing Education, Kumasi Polytechnic-Ghana for his technical advice and also to Abdul Hamid Kwarteng for his support and guidance.

\section{References}

Alternative Dispute Resolution Act, 2110. (2010). Act 663, Section 32.

Alternative Dispute Resolution Act. (2010). Act 663, Section 2.

Alternative Dispute Resolution Act. (2010). Section 14(I).

Alternative Dispute Resolution Act. (2010). Section 14(II).

Alternative Dispute Resolution Act. (2010). Section 16.

Alternative Dispute Resolution Act. (2010). Section 24(3).

Alternative Dispute Resolution Act. (2010).Section 22.

Alternative Dispute Resolution Act. (2010).Section 26(1).

Arbitration Agreement in OHADA and People's Republic of China Arbitration Laws. Journal of Politics and Law. Vol. 4, No. 1.

Arbitration Convention at 49 .

Arbitration Law of the People's Republic of China (promulgated by the Standing Comm. Nat'l People's Cong., Aug. 31, 1994, effective Sep. 1, 1995) (Law info china).

Arbitration, West's Encyclopedia of American Law. (2008). (2nd ed.). Retrieved February 9, 2016, from http://legal-dictionarythefreedictionary.com/arbitration

Article 10 of China Arbitration Law.

Article 11.2 of the Administered Arbitration Rules of Hong Kong International Arbitration Centre. Retrieved from http://www.hkiac.org/index.php/en/arbitration-rules-a-guidelines/hkiacadministered -arbitration-rules

Article 16 of China's Arbitration Ac.

Article 17 Preservation of Property, CIETAC Arbitration Rules, p. 27, arts. 17, 18.

Article 20 of PRC Arbitration Law, p. 4.

Article 22 of CIETAC Rules. (2000).

Article 26 of UNCITRAL Arbitration Rules (1976), Article 17 of UNCITRAL Model Law on International Commercial Arbitration (1985).

Article 34(4) of China Arbitration Law, 4.

Article 58 of China Arbitration Law.

Article 58(6) of China Arbitration Law, 4.

Article 9 of the Rules of Arbitration of ICC Court of Arbitration provides Int'l Chamber of Commerce, Rules of Arbitration. (2010).

Articles 16 and 18 of China Arbitration Law.

Articles 16 and 18 of PRC Arbitration Law, p. 4.

Bennett, J. S. (2010). Saving Time and Money by Using Alternative Dispute Resolution for Intellectual Property Disputes-WIPO to the Rescue. Rev. Jur. UPR, 79, 389.

Chi Manjiao. (2008). Is the Chinese Arbitration Act Truly Arbitration- Friendly: Determining the Validity of Arbitration Agreement under Chinese Law. Asian International Arbitration, Journal 4, 104, 111.

China Arbitration Law, art. 16(4).

China International Economic and Trade Arbitration Commission (CIETAC) Arbitration Rules, art 81(1).

Chu Yongchang. (2011). Analysis on the Ad hoc Arbitration System and the Open up of Chinese Arbitration 
Market. Retrieved from http://cn.cietac.org/magzine/100-8.shtml.

Contract Law of the People's Republic of China Art. 11 (promulgated by the Nat'l People's Cong., Mar. 15, 1999, effective Oct. 1, 1999) (Law info china) (China) [hereinafter China Contract Law].

Convention on the Recognition and Enforcement of Foreign Arbitral Awards. (1958) 21 U.S.T. 2517, 330 U.N.T.S. 3 [hereinafter Arbitration Convention].

Farina, A. J. (2011). "Talking Disputes Into Harmony" China Approaches International Commercial Arbitration. American University International Law Review, 4(1), 137-171.

Gao, C. D. (2008). Debate and Resolution Methods for Recognition and Enforcement of Non-domestic Awards by Courts of Our State Commercial Arbitration Review, University of International Business and Economics Press, Vol. 3: 89.

Hong Kong Int'l Arbitration Centre. (1993). Revised Guide to Arbitration under the Domestic Arbitration Rules. 2-3

Kimathi Kuenyehia, Sr. (2011). Arbitration 2011. Law Business Research.

Kwadwo Sarkodie. (2011). Arbitration in Ghana-The Alternative Dispute Resolution Act 2010, the Mayer Brown Practices-International Construction Law Review, 3.

Melanie Willems. (2014). That's A Relief (Interim): The English Court's Approach in Arbitrations, Andrews Kurth.

Morris, Z. S. (2009). The truth about interviewing elites. Politics, 29(3), 209-217. http://dx.doi.org/10.1111/j.1467-9256.2009.01357.x

Nene A. O. Amegatcher. (2011). A Daniel Comes to Judgment: Ghana's ADR Act. A Progressive or Retrogressive Piece of Legislation. Paper delivered at the Ghana Bar Association Annual Conference.

New York Convention Section 59(3).

St. Council of the People's Republic of China, art. 15. (2001). Regulations on Administration of Foreign Law Firms' Representative Offices in China.

Supreme People's Court. (2003). Min Si Ta Zi, No. 23.

Tao, J. Z. (2008). Chinese Legal Environment for International Arbitration. Dispute Resolution International, 2 , $295,299$.

Tao, J. Z. (2008). One Award - Two Obstacles: Double Trouble When Enforcing Arbitral Awards in China, 4 ASIAN INT'L ARB. J. 83-84.

Tao, J. Z. (2011). "Salient Issues in Arbitration in China." Am. U. Int'l L. Rev. 27, 807.

Tao, J. Z., \& von Wunschheim, C. (2007). Articles 16 and 18 of the PRC Arbitration Law: The Great Wall of China for Foreign Arbitration Institutions. Arbitration International 23, 309. http://dx.doi.org/10.1093/arbitration/23.2.309

U.S. Department of State. (2015). Investment Climate Statements-Ghana. Retrieved from http://www.state.gov/e/eb/rls/othr/ics/2015/241574.htm

Ulrike Gluck and Falk Lichtenstein. (2014).Arbitration In the People's Republic of China, Arbitration in the People's Republic of China, Invest4Justice.

Van Den Berg. (1996). "Court Decisions on the New York Convention" in: The New York Convention of 1958, ASA Special Series No. 9, 61.

WIPO. (n.d). What is arbitration? Retrieved February 9, 2016, from http://www.wipo.int/amc/en/arbitration/what-is-arb.html

Xia, X. H. (2011). Implementation of the New York Convention in China. International Commercial Arbitration Brief, 1(1), 20-24.

Yuan, W. (2013). Introduction and comparison of Chinese arbitration system. Retrieved January 4, 2016, from http://telc.jura.uni-halle.de/sites/default/files/BeitraegeTWR/Heft126.pdf

Zhao, X. W. (2007). Review of Recognition and Enforcement of Foreign Ad Hoc Arbitration Awards in China through the Aoetker Case, Zheng Fa Lun Cong, No.3.

\section{Copyrights}

Copyright for this article is retained by the author(s), with first publication rights granted to the journal.

This is an open-access article distributed under the terms and conditions of the Creative Commons Attribution license (http://creativecommons.org/licenses/by/4.0/). 